\title{
Esophageal Mass
}

National Cancer Institute

\section{Source}

National Cancer Institute. Esophageal Mass. NCI Thesaurus. Code C35490.

An abnormal growth located in the esophagus. 